Article

\title{
Air Cleaning Performance of Two Species of Potted Plants and Different Substrates
}

\author{
Tatiana Armijos-Moya ${ }^{1, *(\mathbb{D})}$, Pieter de Visser ${ }^{2}$, Marc Ottelé ${ }^{3}\left(\mathbb{D}\right.$, Andy van den Dobbelsteen ${ }^{1}$ (D) \\ and Philomena M. Bluyssen ${ }^{1}$ (D)
}

1 Faculty of Architecture and the Built Environment, Delft University of Technology, 2628 BL Delft, The Netherlands; A.A.J.F.vandenDobbelsteen@tudelft.nl (A.v.d.D.); P.M.Bluyssen@tudelft.nl (P.M.B.)

2 Wageningen Plant Research, Wageningen University and Research, 6708 PB Wageningen, The Netherlands; pieter.devisser@wur.nl

3 Faculty of Civil Engineering \& Geosciences, Delft University of Technology, 2628 CN Delft, The Netherlands; M.Ottele@tudelft.nl

* Correspondence: T.E.ArmijosMoya@tudelft.nl; Tel.: +31-15-278-9752

Citation: Armijos-Moya, T.; de Visser P.; Ottelé, M.; van den Dobbelsteen,

A.; Bluyssen, P.M. Air Cleaning Performance of Two Species of Potted Plants and Different Substrates. Appl. Sci. 2022, 12, 284. https://doi.org/ 10.3390/app12010284

Academic Editor: Elza Bontempi

Received: 22 November 2021

Accepted: 24 December 2021

Published: 28 December 2021

Publisher's Note: MDPI stays neutral with regard to jurisdictional claims in published maps and institutional affiliations.

Copyright: (C) 2021 by the authors. Licensee MDPI, Basel, Switzerland. This article is an open access article distributed under the terms and conditions of the Creative Commons Attribution (CC BY) license (https:// creativecommons.org/licenses/by/ $4.0 /)$.

\begin{abstract}
Potted plants have been reported to uptake VOCs and help "cleaning" the air. This paper presents the results of a laboratory study in which two species of plants (peace lily and Boston fern) and three kinds of substrates (expanded clay, soil, and activated carbon) were tested and monitored on their capacity to deplete formaldehyde and $\mathrm{CO}_{2}$ in a glass chamber. Formaldehyde and $\mathrm{CO}_{2}$ were selected as indicators to evaluate the biofiltration efficacy of 28 different test conditions; relative humidity $(\mathrm{RH})$ and temperature $(\mathrm{T})$ were monitored during the experiments. To evaluate the efficacy of every test, the clean air delivery rate (CADR) was calculated. Overall, soil had the best performance in removing formaldehyde $\left(\sim 0.07-0.16 \mathrm{~m}^{3} / \mathrm{h}\right)$, while plants, in particular, were more effective in reducing $\mathrm{CO}_{2}$ concentrations (peace lily $0.01 \mathrm{~m}^{3} / \mathrm{h}$ ) (Boston fern $0.02-0.03 \mathrm{~m}^{3} / \mathrm{h}$ ). On average, plants $\left(\sim 0.03 \mathrm{~m}^{3} / \mathrm{h}\right)$ were as effective as dry expanded clay $\left(0.02-0.04 \mathrm{~m}^{3} / \mathrm{h}\right)$ in depleting formaldehyde from the chamber. Regarding air-cleaning performance, Boston ferns presented the best performance among the plant species, and the best performing substrate was the soil.
\end{abstract}

Keywords: phytoremediation; botanical biofiltration; indoor air quality; plant monitoring; clean air delivery rate; formaldehyde

\section{Introduction}

Studies have shown that poor indoor air quality (IAQ) affects human health in longterm exposure [1]. In the INDEX project [2,3], several chemicals, their concentration levels, and their toxicity information were analyzed and evaluated in indoor environments. It was concluded that volatile organic compounds (VOCs), such as benzene, toluene, and xylene, together with aldehydes, should be considered as priority pollutants regarding their health effects. Several studies related with IAQ have indicated that VOCs are emitted by indoor sources such as building materials, furnishings, and cleaning products [4-8]. In 1998, Yu and Crump published a review on VOC emissions from newly built houses [9]. They stated that building material emissions are the sources of VOCs in the indoor environment, especially during the first six months after construction [9]. Among the indoor pollutants, VOCs are ubiquitous and have harmful effects on human health, such as asthma, wheezing, allergic rhinitis, and eczema.

VOCs are frequently classified according to their boiling point [10]: very volatile organic compounds (VVOCs), such as formaldehyde; VOCs, such as solvents and terpenes; semi VOCs (SVOCs), such as pesticides; and particulate organic matter (POM), such as biocides. Regarding IAQ, VOCs and VVOCs are the pollutants most frequently found indoors [11]. Some of them are toxic and carcinogenic, such as formaldehyde, and, in 
general, exposure to formaldehyde is higher indoors than outdoors [12-14]. Formaldehyde $\left(\mathrm{CH}_{2} \mathrm{O}\right)$ is a highly reactive aldehyde. It is a ubiquitous pollutant and it is a component of different chemical and industrial products [14]. Because of its occurrence indoors and the evident impact on human health, the study presented focused on the reduction of indoor formaldehyde concentrations.

\subsection{Sources of Formaldehyde}

Formaldehyde is released directly into the indoor air from various types of sources. People are exposed to environmental formaldehyde from adhesives, lubricants, wall coverings, rubber, water-based paints, cosmetics, electronic equipment, and glued wood-based products. For instance, formaldehyde is known to be emitted considerably by chipboard, MDF, plywood, and other wood-based products containing resins [5,8]. Next to these building materials, formaldehyde is a component of tobacco smoke and of combustion gases from heating stoves and gas appliances. It is used as a disinfectant and as a preservative in biological laboratories. It is also used in the fabric and clothing industry.

Major sources of formaldehyde in nonsmoking environments are building materials and consumer products. This applies to new materials and products and can last several months, especially in conditions with high relative humidity $(\mathrm{RH})$ and high indoor temperatures [14-16]. Formaldehyde is also one of the main components for resins, which are contained in various products, mainly in wood products. Furthermore, it should be noted that secondary formation of formaldehyde occurs in air through the oxidation of VOCs. However, the influence of these secondary chemical processes on the ambient and indoor concentrations has still not been fully measured [17].

\subsection{Health Effects of Formaldehyde}

In general, humans are mainly exposed to formaldehyde through inhalation. As formaldehyde is soluble in water, it is rapidly absorbed in the respiratory and gastrointestinal tracts and metabolized [1]. Predominant symptoms of formaldehyde exposure in humans are irritation of the eyes, nose, and throat, discomfort, sneezing, coughing, and nausea, among others [18]. The lowest concentration may cause sensory irritation of the eyes with humans, increasing eye blink frequency and conjunctival redness [1].

\subsection{Formaldehyde Guidelines and Regulations}

In The Netherlands, several formaldehyde measurement studies have been executed, especially in homes and at schools, where there were complaints which might have been caused by formaldehyde. Several complaints were connected with a concentration above $120 \mu \mathrm{g} / \mathrm{m}^{3}$. In Dutch schools, the highest concentration measured was $2.5 \mathrm{mg} / \mathrm{m}^{3}$. In homes [15], the highest concentrations found were between 0.75 and $1 \mathrm{mg} / \mathrm{m}^{3}$. In 2011 [19], Van Gemert reported that the odor thresholds for formaldehyde can fluctuate from 0.03 to $2.2 \mathrm{mg} / \mathrm{m}^{3}$.

WHO 2010 reported that the lowest concentration to cause sensory irritation of the eyes in humans is $0.38 \mathrm{mg} / \mathrm{m}^{3}$ for four hours [1]. Furthermore, a formaldehyde concentration of $0.6 \mathrm{mg} / \mathrm{m}^{3}$ increases eye blink frequency and conjunctival redness. Regarding the perception of odor of formaldehyde, some individuals reported sensory irritation, and formaldehyde may be perceived at concentrations below $0.1 \mathrm{mg} / \mathrm{m}^{3}$. However, this is not considered to be an adverse health effect $[1,17,18]$.

\subsection{Effects of Plants on Formaldehyde Removal}

It has been well established that potted plants can help to phytoremediate a diverse range of indoor air pollutants. In particular, a substantial body of literature has demonstrated the ability of the potted plant system to remove VOCs from the indoor air. These findings have largely originated from laboratory-scale chamber experiments, with several studies drawing different conclusions regarding the primary VOC removal mechanism and removal efficacies [20-23]. The process of VOC depletion found in most studies is 
through the microbial activity in the substrate and rhizosphere, where bacteria absorb the VOCs and metabolize them as a nutrient source [22-25]. It is also important to consider that plant selection has a significant impact on the depletion of gaseous pollutants from the air $[21-23,26,27]$; therefore, one of the main aims of this study is to execute controlled laboratory experiments to select the best components to build up an active plant-based system that will aim to improve indoor air quality.

In 2011, Aydogan and Montoya tested the formaldehyde removal efficiency of the root area and aerial parts independently and found that while the aerial parts of plants were capable of VOC removal, removal by the root area occurred at a substantially faster rate [25]. Other research has identified the potential for the microorganisms existing on and in leaves to remove VOCs $[28,29]$. However, most recent research has acknowledged that the mechanisms of removal are mainly located in the substrate, rather than the plant itself [30-32].

Based on the studies mentioned, it is valid to assume that a plant together with its substrate can have a positive removal effect on the concentration of formaldehyde in indoor environments. However, the extent to which different plants remove formaldehyde is not well known yet. This paper presents the results of a study on the uptake of formaldehyde and $\mathrm{CO}_{2}$ from selected potted plants and substrates, with the objective of using the outcome of these experiments to select the best-performing plant and substrate for the construction of an indoor plant-based system (biowall).

\section{Materials and Methods}

\subsection{Experimental Setup}

The setup, schematically presented in Figure 1, consisted mainly of a dynamic chamber. The dynamic chamber was made out of glass with an inner diameter of $28 \mathrm{~cm}$, height of $60 \mathrm{~cm}$, and volume $(\mathrm{V})$ of $0.033 \mathrm{~m}^{3}$. The glass chamber had three air entrances that were sealed during the tests. The gas stream of $300 \mathrm{ppb}$ concentration of formaldehyde, which is described in Section 2.2, was released directly inside of the chamber by heating the formaldehyde solution through a heat source.

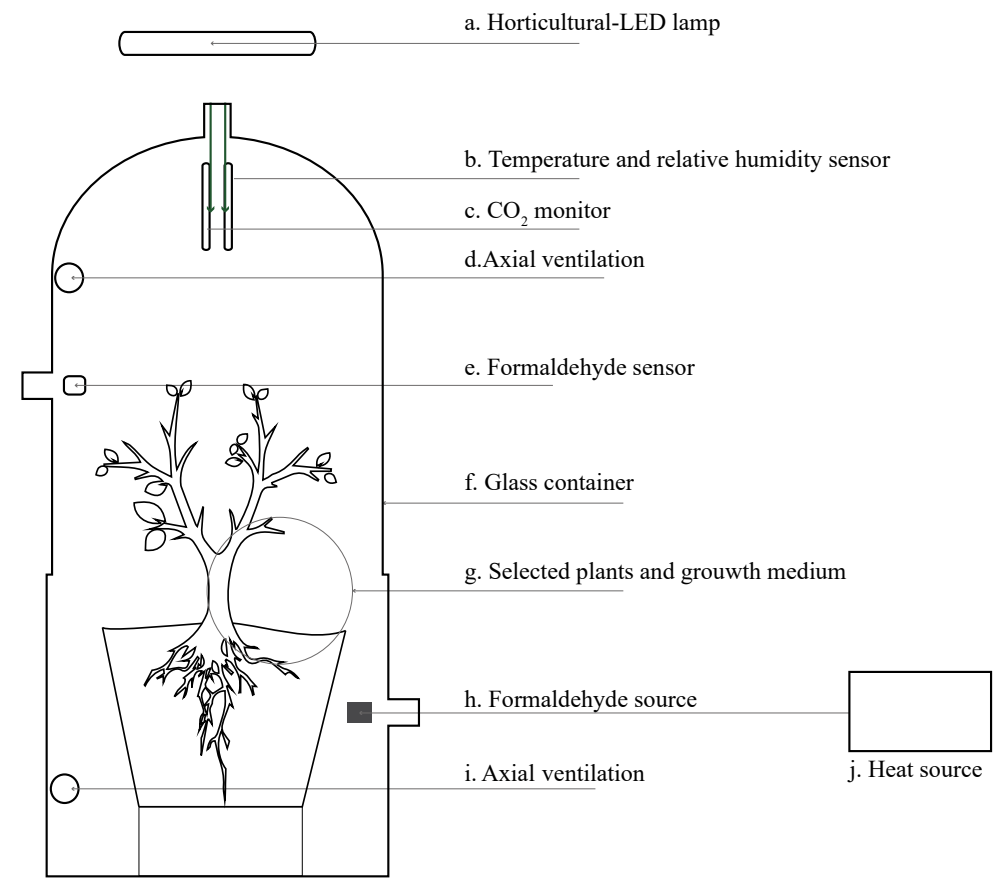

Figure 1. Schematic view of the experimental setup.

The actual formaldehyde concentration was determined by a formaldehyde sensor (DART-sensor $11 \mathrm{~mm}$, calibrated, ppb-level, lower detection limit of $<30 \mathrm{ppb}$, response 
time (T90) $<30 \mathrm{~s}$, resolution $10 \mathrm{ppb}$ ). Two axial fans were placed into the glass chamber to distribute the air evenly within the chamber. The sensor performed a measurement every minute. During the tests, an LED growing lamp was activated $\left(1500 \mu \mathrm{molm}^{-2} \mathrm{~s}^{-1}\right.$ $\left.1900 \mu \mathrm{molm}^{-2} \mathrm{~s}^{-1}\right)$, and the temperature, relative humidity, and $\mathrm{CO}_{2}$ levels were also monitored. $\mathrm{CO}_{2}$ levels were monitored with VAISALA $\mathrm{CO}_{2}$ probe GMP252 (ppm-level). Furthermore, the glass container was sealed with a solvent-free, plastic, self-adhesive sealant kneading material, based on synthetic rubber during the tests.

\subsection{Formaldehyde Source}

The formaldehyde solution used for these experiments was Solution Sigma F8775, $25 \mathrm{~mL}$ (36.5-38\% formaldehyde in $\mathrm{H}_{2} \mathrm{O}$ ). The formaldehyde solution was mixed with demi-water in order to generate $300 \mathrm{ppb}$ within the chamber. The mixture was executed by technicians in the laboratories of the University of Wageningen, as follows:

- $\quad 10 \mu \mathrm{L}$ formaldehyde $+90 \mu \mathrm{L}$ demi-water $=100 \mu \mathrm{L}$ (final mixture).

- $10 \mu \mathrm{L}$ of the final mixture generated $300 \mathrm{ppb}$ of formaldehyde, within the chamber.

It is important to report that the formaldehyde solution contained $10-15 \%$ of methanol as stabilizer to prevent polymerization. The DART-sensor is also sensitive to methanol. Therefore, by introducing formaldehyde, a small amount of methanol was introduced as well. The response of the DART-sensor to this amount of methanol therefore also needed to be tested.

\subsection{Selection and Preparation of the Substrates}

Three different growth media were chosen for the test: soil, activated carbon, and expanded clay. The selected potting soil was composed of peat, green compost, lime, and fertilizers. The selection of the substrates was based on previous studies and because they are common substrates available on the market $[24,25]$. For every type of substrate, six tests were executed: three with a dry substrate and three with a wet substrate. The substrates were each placed in a plastic container with a capacity of $1.1 \mathrm{~L}\left(0.0011 \mathrm{~m}^{3}\right)$ with $0.14 \mathrm{~m}$ diameter in the upper part, which was the exposed area of the substrate.

\subsection{Selection and Preparation of the Plant Samples}

Two different plant species were tested: Spathiphyllum Wallisii Regel (common name: peace lily) and Nephrolepis exaltata L. (common name: Boston fern) (Figure 2). Three plants of every species were chosen for the tests, and they were selected with similar characteristics of age and size (peace lily: $0.35 \mathrm{~m}$ height; Boston fern: $0.30 \mathrm{~m}$ height). The plants were selected as potential air cleaners based on information gathered by previous studies, which demonstrated that the capability of these species in uptake of some VOCs was good $[30,33,34]$, and they were also chosen because they can be used in living wall systems (LWSs) and/or green walls and are commonly used for indoor decoration. The plants were bought in a house-plant shop in the Netherlands and were repotted 25 days prior to the experiments, to minimize the stress of the plant, in a $14 \mathrm{~cm}$ diameter plastic pot of $1.1 \mathrm{~L}\left(0.0011 \mathrm{~m}^{3}\right)$ of expanded clay growth medium. The expanded clay was selected as a growth medium for the tests because it is the most common substrate used indoors and it is most suitable for use in indoor living wall systems. All the plants underwent a $30 \mathrm{~min}$ acclimatization and adaptation process in the laboratory, where they were exposed to similar conditions, in order to minimize the stress of the plants prior to the execution of the tests. 


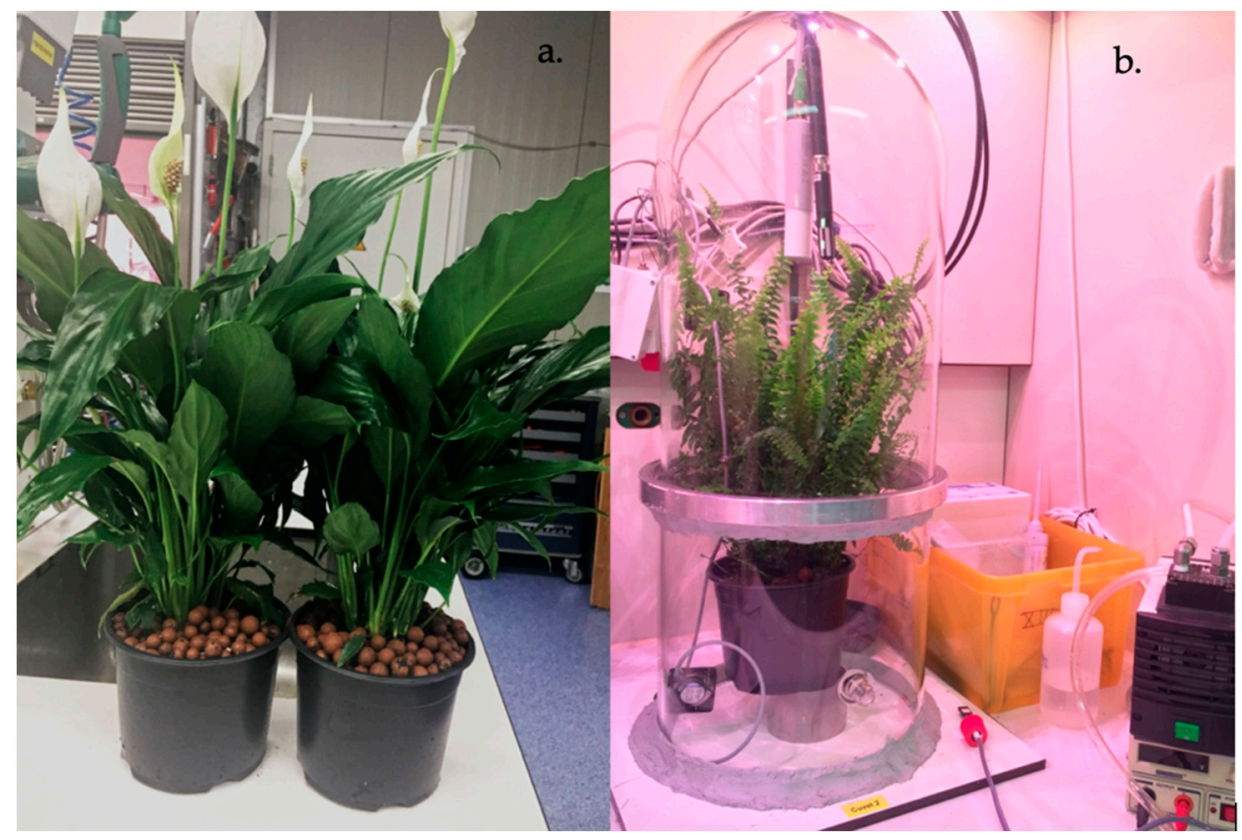

Figure 2. Selected plants: (a) Spathiphyllum Wallisii Regel (common name: peace lily); (b) Nephrolepis exaltata L. (common name: Boston fern) in the glass container.

\subsection{Procedure}

Two zero-measurement evaluations were performed to establish the conditions of the setup in the glass container in which the depletion of the formaldehyde took place: one at the beginning of the test series and one at the end. Similarly, two extra zero-measurement evaluations were performed with a plastic container that had the same characteristics of the containers that were used during every test.

The measurements were executed for 1-1.5 $\mathrm{h}$ until the formaldehyde was depleted or stabilized in the chamber. Gas concentrations were measured in $\mathrm{ppb}$ in the case of formaldehyde and in ppm in the case of $\mathrm{CO}_{2}$. For further analysis, the concentrations of these gases were expressed as micrograms per cubic meter $\left(\mu \mathrm{g} / \mathrm{m}^{3}\right)$ and milligrams per cubic meter, respectively. For each test, $\sim 368.48 \mu \mathrm{g} / \mathrm{m}^{3}(\sim 300 \mathrm{ppb})$ of formaldehyde was released in the chamber to generate exactly the same condition every time.

Each set of experiments was conducted three times, in order to consistently evaluate each condition tested (Tables 1 and 2). For each test, the glass container was wiped with a wet paper towel after each measurement. The plastic container with the substrate or plant sample was placed in the center of the glass chamber. Depending on the height of the plant, a stainless-steel base was placed at the bottom (stainless steel is an inert material).

A small plate connected to a heat source was placed in the lower hole, and $10 \mu \mathrm{L}$ of formaldehyde solution was placed on the plate with a pipette. After a drop of formaldehyde solution was placed on the plate, the hole was closed, and the heat source was activated in order to realize the solution in the air. This was the beginning of the test. During the tests with the Boston ferns, it was necessary to inject some $\mathrm{CO}_{2}$ when the level was lower than $\sim 410 \mathrm{ppm}\left(\sim 738 \mathrm{mg} / \mathrm{m}^{3}\right)$ which is the global atmospheric $\mathrm{CO}_{2}$ concentration (average outdoor concentration) $[35,36]$ and is sufficient for the plants to grow, although some studies have shown that the optimal $\mathrm{CO}_{2}$ concentration is around $900 \mathrm{ppm}$ [37].

To calculate the amount of formaldehyde depleted inside of the chamber, the following formula was used [38]:

$$
-\lambda=\frac{\ln \left(\frac{N(t)}{N(0)}\right)}{t}
$$

where $\lambda=$ Decay rate $\left(\mathrm{h}^{-1}\right)$.

$$
N(t)=\text { Amount of pollutant after time } t\left(\mu \mathrm{g} / \mathrm{m}^{3}\right) \text { or }\left(\mathrm{mg} / \mathrm{m}^{3}\right) \text {. }
$$


$N(0)=$ Initial amount of pollutant at $t=0 h\left(\mu \mathrm{g} / \mathrm{m}^{3}\right)$ or $\left(\mathrm{mg} / \mathrm{m}^{3}\right)$.

To calculate the rates of contaminant reduction in the test chamber, the clean air delivery rate (CADR) was calculated $[39,40]$ :

$$
C A D R=(\lambda e-\lambda n-\lambda p) V
$$

where $\lambda e=$ Total decay rate $\left(\mathrm{h}^{-1}\right)$.

$\lambda n=$ Natural decay rate which is the reduction of the contaminant due to natural phenomena in the test chamber $\left(\mathrm{h}^{-1}\right)$.

$\lambda p=$ Decay rate when the plastic pot was placed in the chamber $\left(\mathrm{h}^{-1}\right)$.

$V=$ Volume of the chamber $\left(\mathrm{m}^{3}\right), 0.033\left(\mathrm{~m}^{3}\right)$.

To calculate the removal efficiency of the different test conditions, the following formula was used [38]:

$$
\eta=\left(\frac{N(0)-N(t)}{N(0)}\right) * 100
$$

where $\eta=$ Efficiency $(\%)$.

$N(t)=$ Amount of pollutant after time $t\left(\mu \mathrm{g} / \mathrm{m}^{3}\right)$ or $\left(\mathrm{mg} / \mathrm{m}^{3}\right)$.

$N(0)=$ Initial amount of pollutant at $\mathrm{t}=0 h\left(\mu \mathrm{g} / \mathrm{m}^{3}\right)$ or $\left(\mathrm{mg} / \mathrm{m}^{3}\right)$.

\begin{tabular}{|c|c|c|c|c|c|c|c|c|c|c|c|c|}
\hline $\begin{array}{l}\text { Test } \\
\text { No. }\end{array}$ & Test Condition & & $\begin{array}{c}\mathrm{RH}^{*} \\
(\%)\end{array}$ & $\begin{array}{l}\mathrm{T}^{*} \\
\left({ }^{\circ} \mathrm{C}\right)\end{array}$ & $\begin{array}{c}\text { Time } \\
\text { (h) }\end{array}$ & $\begin{array}{c}N(0) \\
\left(\mu \mathrm{g} / \mathrm{m}^{3}\right)\end{array}$ & $\begin{array}{c}N(t) \\
\left(\mu \mathrm{g} / \mathrm{m}^{3}\right)\end{array}$ & $\begin{array}{c}\lambda e \\
\text { (h) }{ }^{-1}\end{array}$ & $\begin{array}{c}\lambda n \\
(\mathbf{h})^{-1}\end{array}$ & $\begin{array}{c}\lambda p \\
(\text { (h) } \\
-1\end{array}$ & $\begin{array}{l}\text { CADR } \\
\left(\mathrm{m}^{3} / \mathrm{h}\right)\end{array}$ & $\begin{array}{c}\eta \\
(\%)\end{array}$ \\
\hline 1 & Zero measurement 1 & (ZM_1) & 53 & 24 & 2.38 & 481.48 & & & 0.09 & & & \\
\hline 2 & Zero measurement 2 & (ZM_2) & 59 & 24 & 1.52 & 524.47 & & & 0.13 & & & \\
\hline 3 & Zero measurement_Pot 1 & (ZMP_1) & 43 & 24 & 2.10 & 498.68 & & & & 0.16 & & \\
\hline 4 & Zero measurement_Pot 2 & (ZMP_2) & 58 & 24 & 1.52 & 515.87 & & & & 0.14 & & \\
\hline 5 & Dry Expanded Clay 1 & (EC_D_1) & 85 & 25 & 1.55 & 363.57 & 98.26 & 0.84 & & & 0.02 & 73 \\
\hline 6 & Dry Expanded Clay 2 & (EC_D_2) & 83 & 24 & 1.13 & 335.32 & 70.01 & 1.38 & & & 0.04 & 79 \\
\hline 7 & Dry Expanded Clay 3 & (EC_D_3) & 57 & 24 & 1.60 & 431.12 & 116.69 & 0.82 & & & 0.02 & 73 \\
\hline 8 & Wet Expanded Clay 1 & (EC_W_1) & 93 & 26 & 1.10 & 308.30 & 1.23 & 5.02 & & & 0.16 & 100 \\
\hline 9 & Wet Expanded Clay 2 & (EC_W_2) & 92 & 25 & 1.10 & 368.48 & 22.11 & 2.56 & & & 0.08 & 94 \\
\hline 10 & Wet Expanded Clay 3 & (EC_W_3) & 95 & 24 & 1.65 & 174.41 & 17.20 & 1.40 & & & 0.04 & 90 \\
\hline 11 & Dry Soil 1 & (S_D_1) & 92 & 24 & 1.27 & 389.36 & 2.46 & 4.00 & & & 0.12 & 99 \\
\hline 12 & Dry Soil 2 & (S_D_2) & 93 & 24 & 1.50 & 336.55 & 4.91 & 2.82 & & & 0.08 & 99 \\
\hline 13 & Dry Soil 3 & (S_D_3) & 93 & 25 & 1.43 & 447.09 & 13.51 & 2.44 & & & 0.07 & 97 \\
\hline 14 & Wet Soil 1 ** & (S_W_1) & 91 & 25 & 1.07 & 197.75 & 1.00 & 4.96 & & & 0.16 & 99 \\
\hline 15 & Wet Soil 2 & (S_W_2) & 96 & 24 & 1.38 & 366.02 & 1.23 & 4.12 & & & 0.13 & 100 \\
\hline 16 & Wet Soil 3 & (S_W_3) & 93 & 24 & 1.48 & 381.99 & 1.23 & 3.87 & & & 0.12 & 100 \\
\hline 17 & Dry Activated Carbon 1 & (AC_D_1) & 41 & 25 & 1.42 & 296.01 & 39.30 & 1.43 & & & 0.04 & 87 \\
\hline 18 & Dry Activated Carbon 2 & (AC_D_2) & 43 & 24 & 1.52 & 297.24 & 45.45 & 1.24 & & & 0.03 & 85 \\
\hline 19 & Dry Activated Carbon 3 & (AC_D_3) & 50 & 24 & 1.49 & 358.65 & 67.55 & 1.13 & & & 0.03 & 81 \\
\hline 20 & Wet Activated Carbon 1 & (AC_W_1) & 95 & 25 & 1.57 & 383.22 & 126.51 & 0.71 & & & 0.01 & 67 \\
\hline 21 & Wet Activated Carbon 2 & (AC_W_2) & 93 & 26 & 1.25 & 428.67 & 128.97 & 0.96 & & & 0.02 & 70 \\
\hline 22 & Wet Activated Carbon 3 & (AC_W_3) & 91 & 24 & 0.75 & 356.20 & 1469.01 & -1.89 & & & - & \\
\hline 23 & Peace Lily 1 & (SPA__1) & 95 & 24 & 1.77 & 311.98 & 41.76 & 1.14 & & & 0.03 & 87 \\
\hline 24 & Peace Lily 2 & (SPA_2) & 95 & 24 & 1.67 & 367.25 & 44.22 & 1.27 & & & 0.03 & 88 \\
\hline 25 & Peace Lily 3 & (SPA_3) & 94 & 24 & 1.72 & 348.83 & 46.67 & 1.17 & & & 0.03 & 87 \\
\hline 26 & Boston fern 1 & (NEPH_1) & 93 & 24 & 1.63 & 390.59 & 58.96 & 1.16 & & & 0.03 & 85 \\
\hline 27 & Boston fern 2 & (NEPH_2) & 94 & 24 & 1.58 & 413.93 & 67.55 & 1.14 & & & 0.03 & 84 \\
\hline 28 & Boston fern 3 & (NEPH_3) & 95 & 24 & 1.55 & 427.44 & 74.92 & 1.12 & & & 0.03 & 82 \\
\hline
\end{tabular}

Table 1. CADR of formaldehyde depletion inside of the chamber.

${ }^{*}$ Mean values; ${ }^{* *}$ The measured formaldehyde concentration was $<0$, the value used for the calculation was $N(t)=$ $1\left(\mu \mathrm{g} / \mathrm{m}^{3}\right)$; Average values used for the calculations: $\lambda n=0.11(\mathrm{~h})^{-1} ; \lambda p=0.15(\mathrm{~h})^{-1}$. 
Table 2. CADR of $\mathrm{CO}_{2}$ depletion inside of the chamber.

\begin{tabular}{|c|c|c|c|c|c|c|c|c|c|c|c|c|}
\hline $\begin{array}{l}\text { Test } \\
\text { No. }\end{array}$ & Test Condition & & $\begin{array}{l}\mathrm{RH}^{*} \\
(\%)\end{array}$ & $\begin{array}{l}\mathrm{T}^{*} \\
\left({ }^{\circ} \mathrm{C}\right)\end{array}$ & $\begin{array}{c}\text { Time } \\
\text { (h) }\end{array}$ & $\begin{array}{c}N(0) \\
\left(\mathrm{mg} / \mathrm{m}^{3}\right)\end{array}$ & $\begin{array}{c}N(t) \\
\left(\mathrm{mg} / \mathrm{m}^{3}\right)\end{array}$ & $\begin{array}{c}\lambda e \\
\text { (h) })^{-1}\end{array}$ & $\begin{array}{l}\lambda n \\
(\mathbf{h})^{-1}\end{array}$ & $\begin{array}{c}\lambda p \\
(\mathbf{h})^{-1}\end{array}$ & $\begin{array}{l}\text { CADR } \\
\left(\mathrm{m}^{3} / \mathrm{h}\right)\end{array}$ & $\begin{array}{c}\eta \\
(\%)\end{array}$ \\
\hline 1 & Zero measurement 1 & (ZM_1) & 53 & 24 & 2.38 & 756.00 & & & 0 & & & \\
\hline 2 & Zero measurement 2 & (ZM_2) & 59 & 24 & 1.52 & 887.40 & & & 0 & & & \\
\hline 3 & Zero measurement Pot 1 & (ZMP 1) & 43 & 24 & 2.10 & 1024.21 & & & & 0 & & \\
\hline 4 & Zero measurement_Pot 2 & (ZMP_2) & 58 & 24 & 1.52 & 1054.81 & & & & 0 & & \\
\hline 5 & Dry Expanded Clay 1 & (EC_D_1) & 85 & 25 & 1.55 & 1368.01 & & 0 & & & - & \\
\hline 6 & Dry Expanded Clay 2 & $\left(\mathrm{EC} \mathrm{D}_{2}\right)$ & 83 & 24 & 1.13 & 1297.81 & 1281.61 & 0.01 & & & 0.00 & 1 \\
\hline 7 & Dry Expanded Clay 3 & (EC_D_3) & 57 & 24 & 1.60 & 1243.81 & & 0 & & & - & \\
\hline 8 & Wet Expanded Clay 1 & (EC_W_1) & 93 & 26 & 1.10 & 1018.81 & & 0 & & & - & \\
\hline 9 & Wet Expanded Clay 2 & (EC_W_2) & 92 & 25 & 1.10 & 1051.21 & 1031.41 & 0.02 & & & 0.00 & 2 \\
\hline 10 & Wet Expanded Clay 3 & (EC_W_3) & 95 & 24 & 1.65 & 1351.81 & 1323.01 & 0.01 & & & 0.00 & 2 \\
\hline 11 & Dry Soil 1 & (S_D_1) & 92 & 24 & 1.27 & 977.40 & & -0.05 & & & - & \\
\hline 12 & Dry Soil 2 & (S_D_2) & 93 & 24 & 1.50 & 1146.61 & & -0.04 & & & - & \\
\hline 13 & Dry Soil 3 & $\left(\mathrm{~S} \mathrm{D}_{3} 3\right)$ & 93 & 25 & 1.43 & 1099.81 & & -0.04 & & & - & \\
\hline 14 & Wet Soil 1 & (S_W_1) & 91 & 25 & 1.07 & 851.40 & & -0.13 & & & - & \\
\hline 15 & Wet Soil 2 & (S W 2) & 96 & 24 & 1.38 & 932.40 & & -0.18 & & & _- & \\
\hline 16 & Wet Soil 3 & (S_W_3) & 93 & 24 & 1.48 & 981.00 & & -0.14 & & & - & \\
\hline 17 & Dry Activated Carbon 1 & (AC_D_1) & 41 & 25 & 1.42 & 2190.61 & & -0.21 & & & - & \\
\hline 18 & Dry Activated Carbon 2 & (AC_D_2) & 43 & 24 & 1.52 & 1002.61 & & -0.06 & & & - & \\
\hline 19 & Dry Activated Carbon 3 & (AC_D_3) & 50 & 24 & 1.49 & 1033.21 & & -0.01 & & & - & \\
\hline 20 & Wet Activated Carbon 1 & (AC_W_1) & 95 & 25 & 1.57 & 1432.81 & & -0.48 & & & - & \\
\hline 21 & Wet Activated Carbon 2 & (AC_W_2) & 93 & 26 & 1.25 & 1222.21 & & -0.09 & & & - & \\
\hline 22 & Wet Activated Carbon 3 & (AC_W_3) & 91 & 24 & 0.75 & 1272.61 & & -0.17 & & & - & \\
\hline 23 & Peace Lily 1 & (SPA_1) & 95 & 24 & 1.77 & 1146.61 & 885.60 & 0.15 & & & 0.01 & 23 \\
\hline 24 & Peace Lily 2 & (SPA_2) & 95 & 24 & 1.67 & 1288.81 & 925.20 & 0.20 & & & 0.01 & 28 \\
\hline 25 & Peace Lily 3 & (SPA_3) & 94 & 24 & 1.72 & 1337.41 & 963.00 & 0.19 & & & 0.01 & 28 \\
\hline 26 & Boston fern 1 & (NEPH_1) & 93 & 24 & 1.37 & 1002.61 & 351.00 & 0.77 & & & 0.03 & 65 \\
\hline 27 & Boston fern 2 & (NEPH_2) & 94 & 24 & 0.97 & 1202.41 & 718.20 & 0.53 & & & 0.02 & 40 \\
\hline 28 & Boston fern 3 & (NEPH_3) & 95 & 24 & 0.92 & 1126.81 & 718.20 & 0.49 & & & 0.02 & 36 \\
\hline
\end{tabular}

${ }^{*}$ Mean values measured in the chamber.

A portable digital leaf area meter named Leafscan was used to scan and calculate the leaf area of the plant species used during the experiment. Every leaf had to be placed on a white background with reference markers. As the three plants of every species had similar characteristics, one plant of every species was selected to be measured where every leaf was scanned and measure separately (Figure 3).

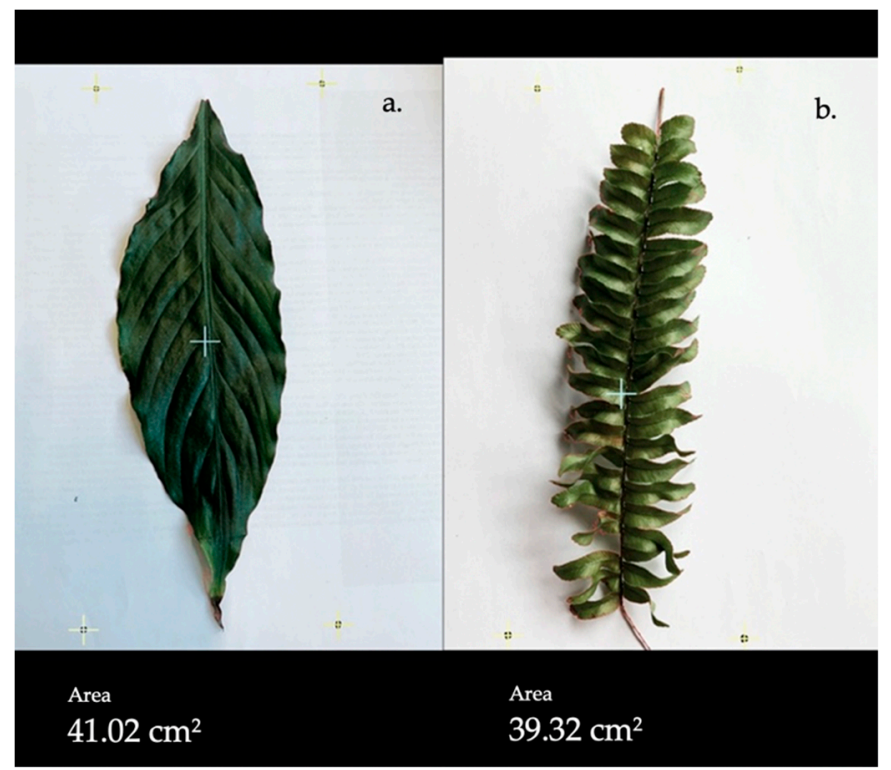

Figure 3. Scan and calculation of the leaf area: (a) peace lily; (b) Boston fern. 
Conversions for chemicals in air were made assuming an air pressure of 1 atmosphere and an air temperature of 25 degrees Celsius. The conversion factor was based on the molecular weight of the chemical and is different for each chemical; in this case, the molecular weight of formaldehyde is $30.031 \mathrm{~g} / \mathrm{mol}$ and of the carbon dioxide $\left(\mathrm{CO}_{2}\right)$ is $44.01 \mathrm{~g} / \mathrm{mol}$ :

Concentration $\left(\mathrm{mg} / \mathrm{m}^{3}\right)=0.0409 \times$ concentration $(\mathrm{ppm}) \times$ molecular weight $(\mathrm{g} / \mathrm{mol})$. Concentration $(\mathrm{ppm})=24.45 \times$ concentration $\left(\mathrm{mg} / \mathrm{m}^{3}\right) \div$ molecular weight $(\mathrm{g} / \mathrm{mol})$. Concentration $\left(\mu \mathrm{g} / \mathrm{m}^{3}\right)=0.0409 \times$ concentration $(\mathrm{ppb}) \times$ molecular weight $(\mathrm{g} / \mathrm{mol})$. Concentration $(\mathrm{ppb})=24.45 \times$ concentration $\left(\mu \mathrm{g} / \mathrm{m}^{3}\right) \div$ molecular weight $(\mathrm{g} / \mathrm{mol})$.

\section{Results}

Figures 4-7 show the measured formaldehyde concentrations for the different test configurations. Figure 8 presents the measured $\mathrm{CO}_{2}$ concentrations when the selected potted plants were included. Figure 9 presents the measured formaldehyde and $\mathrm{CO}_{2}$ concentrations when the Boston ferns were included. In general, three measurements were executed for every test condition, and the figures present the mean values including standard errors $( \pm S E)$. In Tables 1 and 2, the CADRs of, respectively, formaldehyde and $\mathrm{CO}_{2}$ depletion inside of the chamber for the different tests are presented. The CADRs were calculated using Equations (1) and (2). The depletion time used in Tables 1 and 2 to calculate the CADR is based on when the lowest levels of formaldehyde and $\mathrm{CO}_{2}$ were detected inside of the chamber. It is important to mention that the time of the depletion of the pollutant inside of the chamber determines the efficacy of the depletion of every element tested.

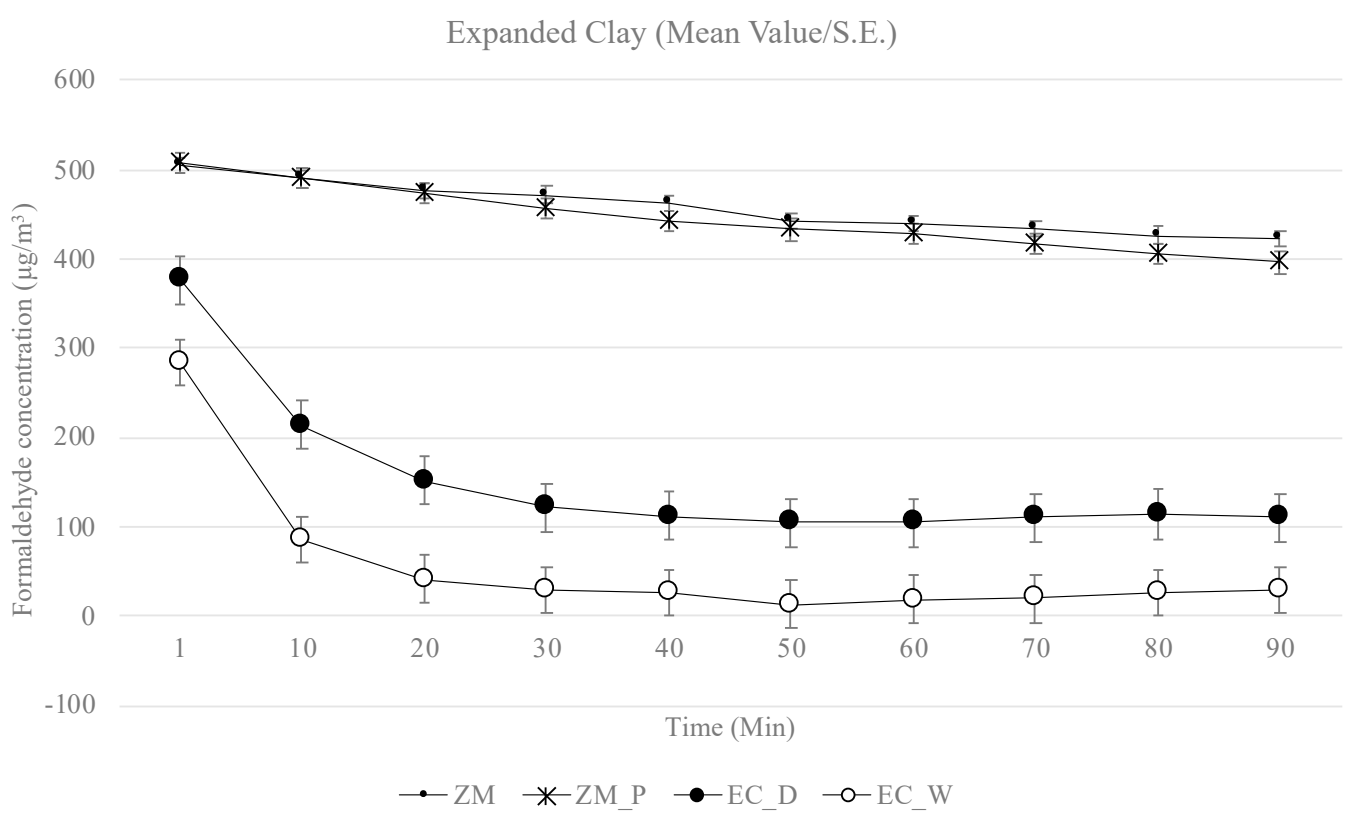

Figure 4. Measured formaldehyde concentration $\left(\left(\mu \mathrm{g} / \mathrm{m}^{3}\right) / \mathrm{h}\right)$ when expanded clay samples were tested: zero measurement $(\mathrm{ZM})$, zero measurement with the plastic pot (ZM_P), dry expanded clay (EC_D), wet expanded clay (EC_W). Data means $\pm \mathrm{SE}, n=3$. 
Soil (Mean Value/S.E.)

600

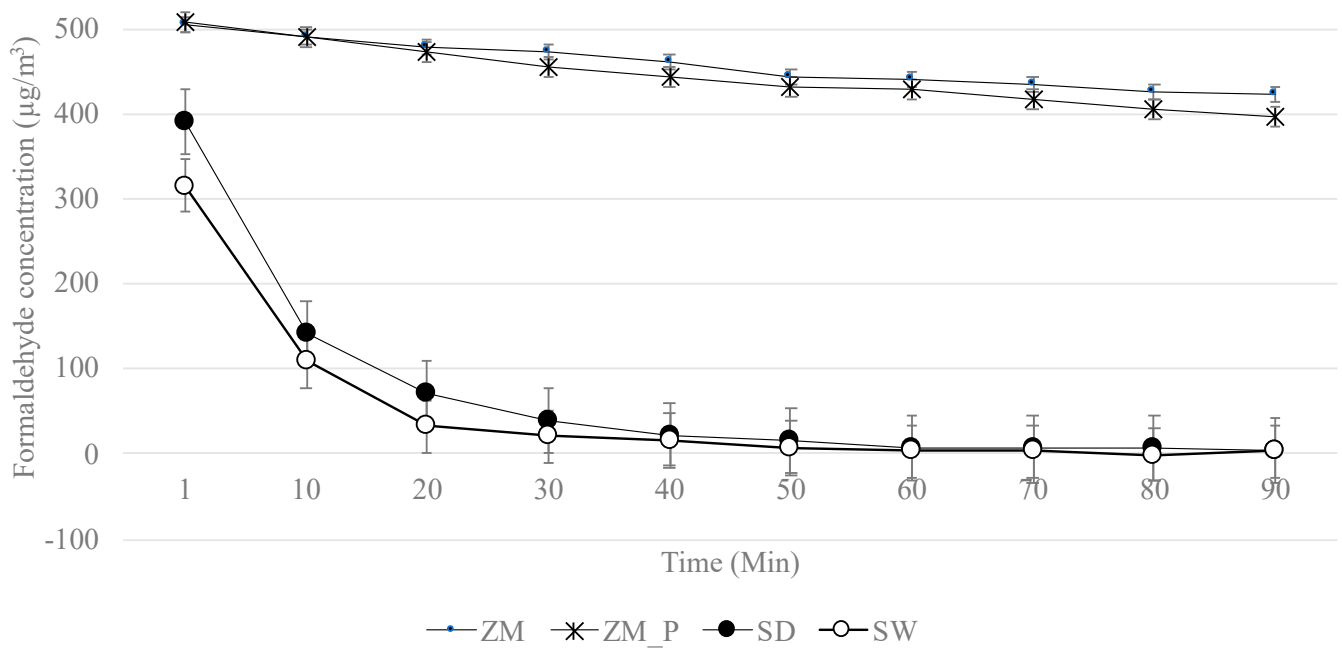

Figure 5. Measured formaldehyde concentration $\left(\left(\mu \mathrm{g} / \mathrm{m}^{3}\right) / \mathrm{h}\right)$ when soil samples were tested: zero measurement (ZM1), zero measurement with the plastic pot (ZM_P), dry soil (SD), wet soil (SW). Data means $\pm \mathrm{SE}, n=3$.

Activated Carbon (Mean Value/S.E.)

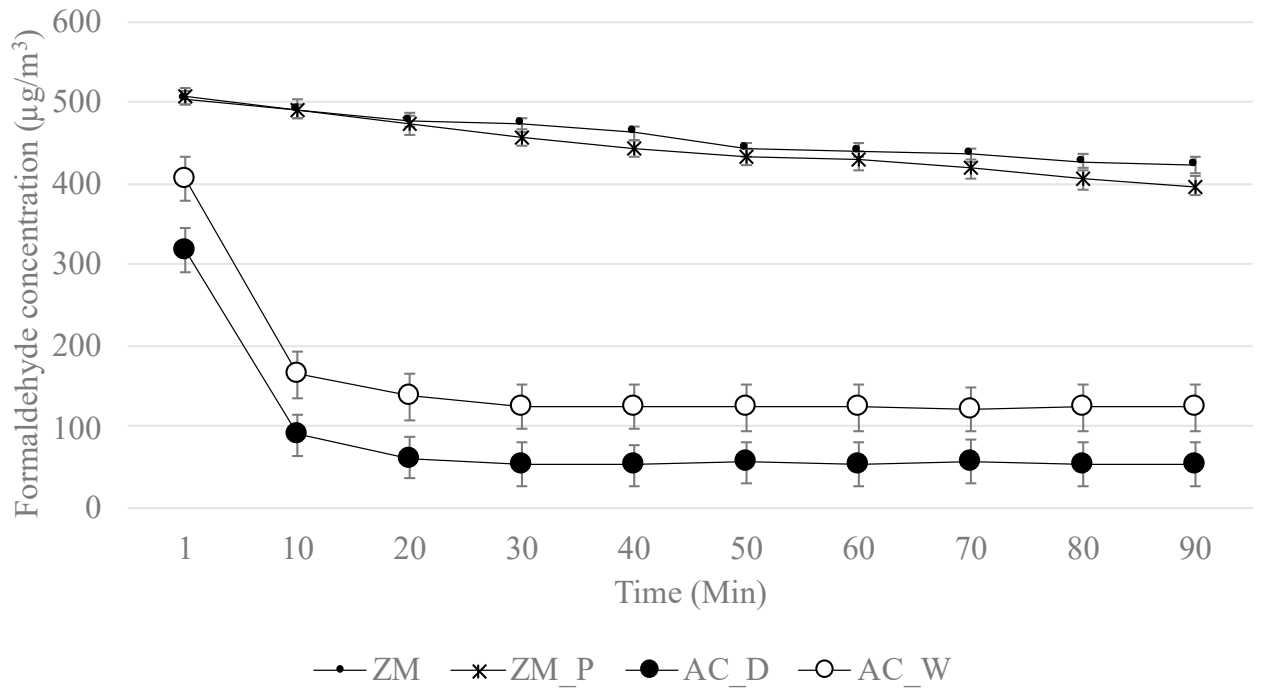

Figure 6. Measured formaldehyde concentration $\left(\left(\mu \mathrm{g} / \mathrm{m}^{3}\right) / \mathrm{h}\right)$ when activated carbon samples were tested: zero measurement $(\mathrm{ZM})$, zero measurement with the plastic pot (ZM_P), dry activated carbon $\left(A C \_D\right)$, wet activated carbon (AC_W). Data means \pm SE, $n=3$ (AC_D), and $n=2$ (AC_W; the third test was excluded). 
Plants (Mean Value/S.E.)

600

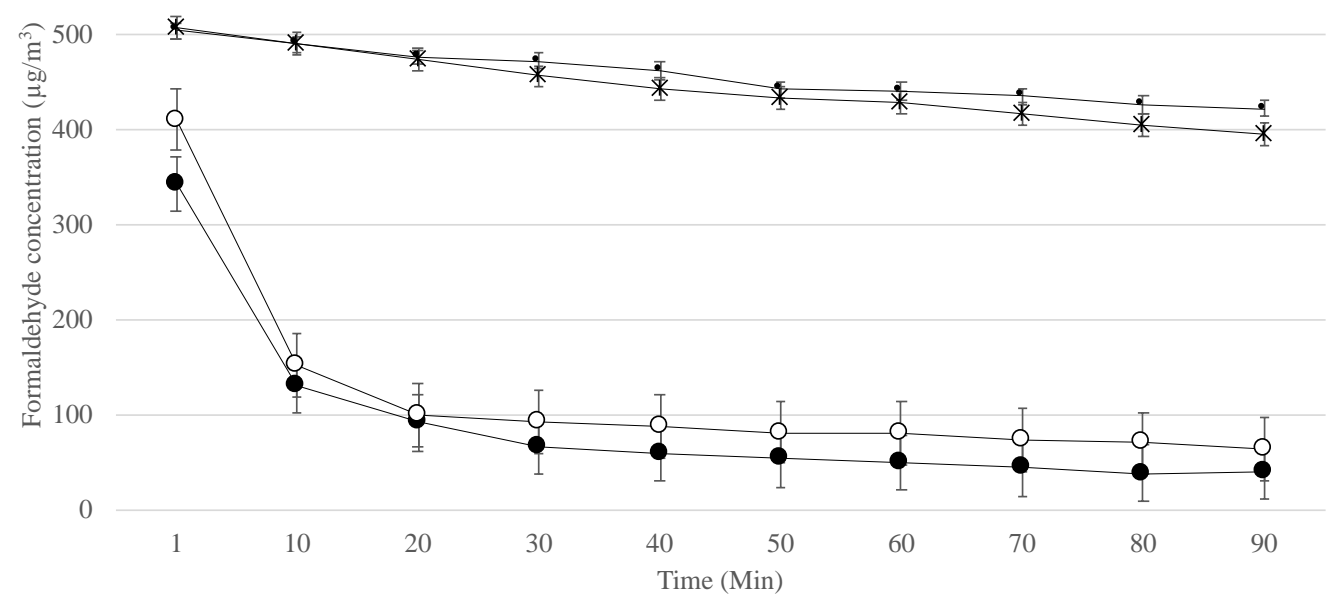

$-\mathrm{ZM} \rightarrow \mathrm{ZM} \_\mathrm{P} \rightarrow \mathrm{SPA}-\mathrm{O}-\mathrm{NEPH}$

Figure 7. Measured formaldehyde concentration $\left(\left(\mu \mathrm{g} / \mathrm{m}^{3}\right) / \mathrm{h}\right)$ when plant samples were tested: zero measurement $(\mathrm{ZM})$, zero measurement with the plastic pot (ZM_P), peace lily (SPA), Boston fern $(\mathrm{NEPH})$. Data means $\pm \mathrm{SE}, n=3$.

Plants (Mean Value/S.E.)

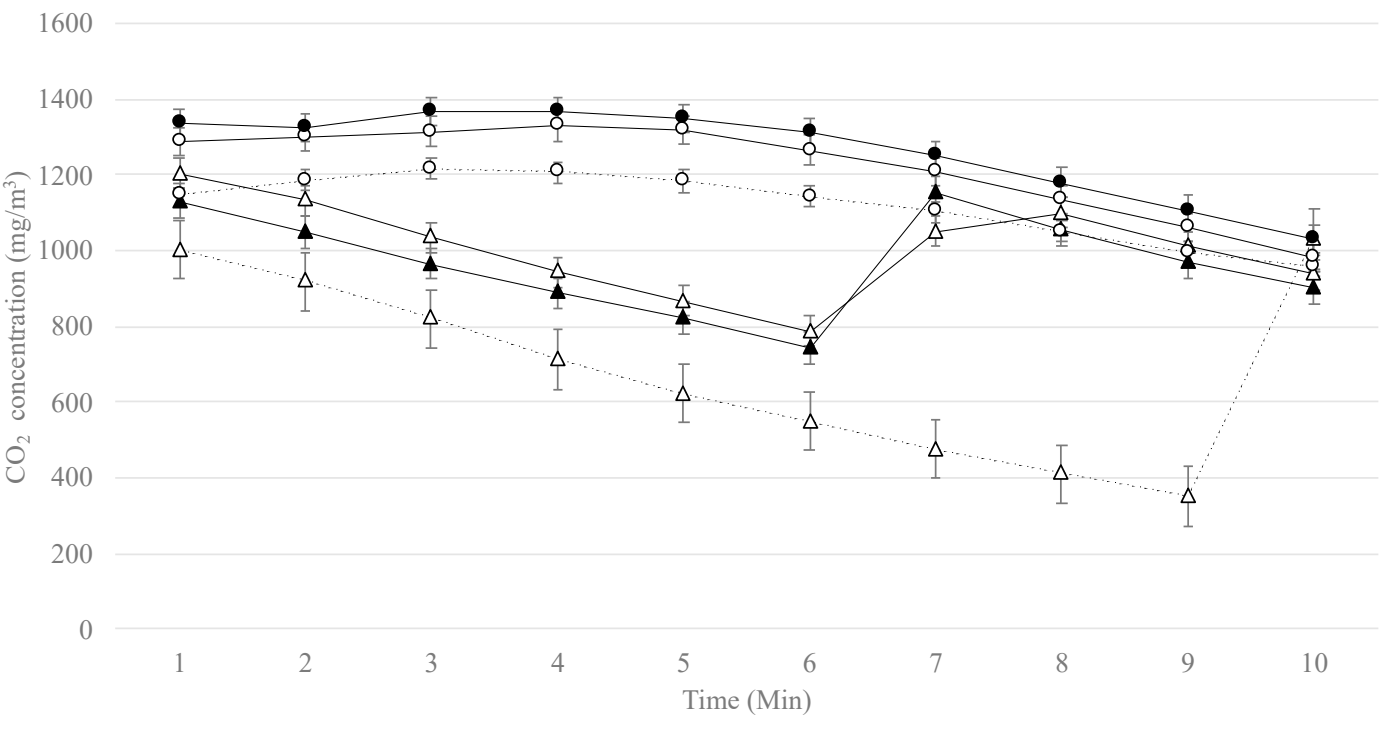

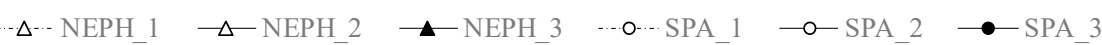

Figure 8. Depletion of $\mathrm{CO}_{2}\left(\mathrm{mg} / \mathrm{m}^{3}\right)$ : for the three Boston ferns (NEPH_1, NEPH_2, and NEPH_3) and for the three peace lilies (SPA_1,SPA_2, and SPA_3). Data means \pm SE, $n=3$. 


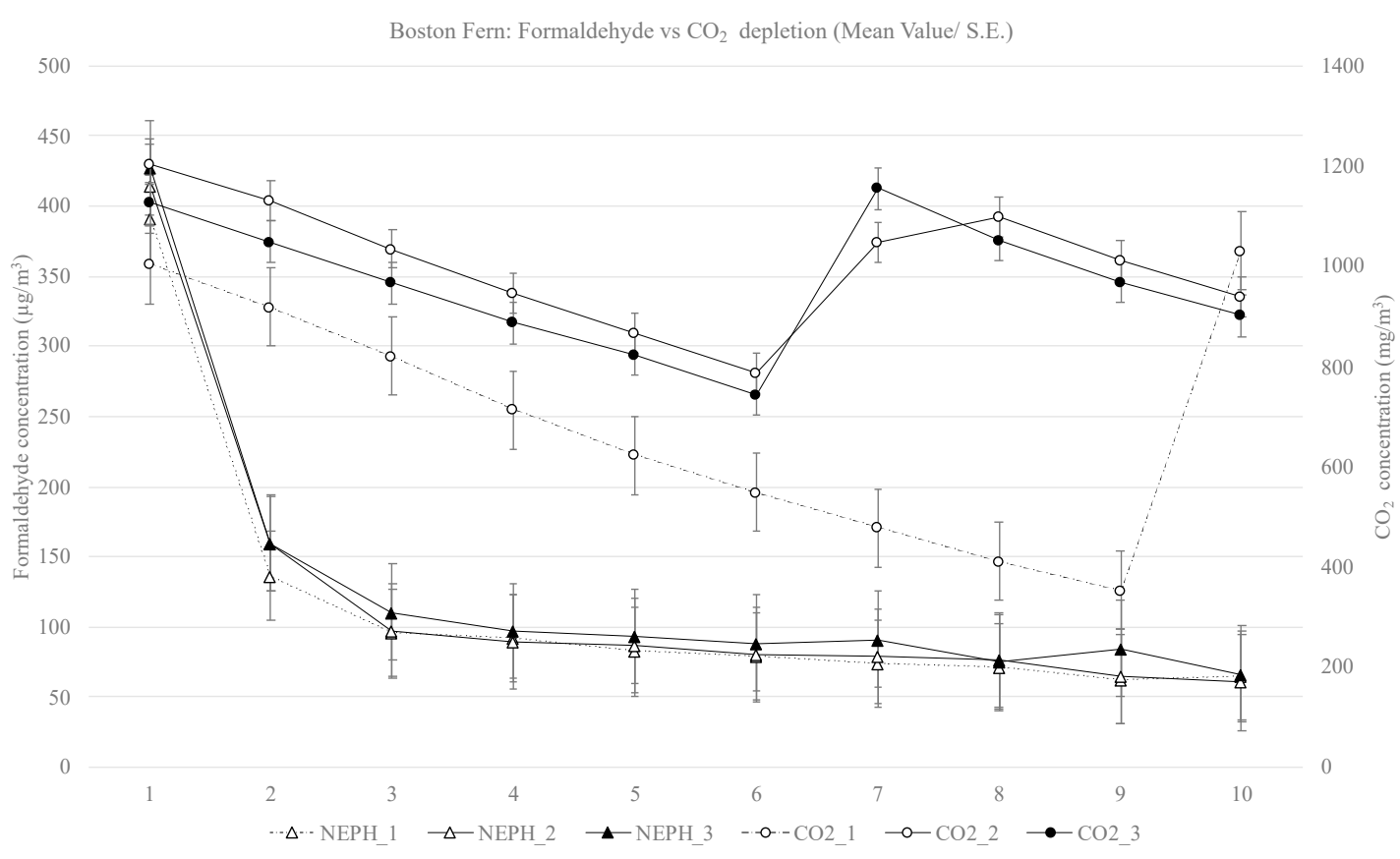

Figure 9. Depletion of formaldehyde (NEPH_1, $\mathrm{NEPH} \_2$, and $\left.\mathrm{NEPH} \_3\right)$ vs. depletion of $\mathrm{CO}_{2}\left(\mathrm{CO}_{2} \_1\right.$, $\mathrm{CO}_{2} \_$, and $\mathrm{CO}_{2} \_$3): for the three Boston ferns. Data means $\pm \mathrm{SE}, n=3$.

During the zero measurements of the setup, the sensor indicated the presence of around $30.7 \mu \mathrm{g} / \mathrm{m}^{3}(25 \mathrm{ppb})$ of formaldehyde in the system. It is believed that this value was due to the calibration process. The zero-measurement tests indicated that the formaldehyde decreased slowly in the chamber (Figures 3-6), which could be the natural decay of the gas or because it was partially adsorbed by the setup. When the plastic container was placed inside of the chamber, the reduction slightly increased, which shows that the formaldehyde was adsorbed by the container. These two values have to be taken in account when analyzing the real effect of the substrates and plants regarding formaldehyde depletion (Table 1). Therefore, to calculate the CADR and establish the real air-cleansing impact of every test condition, the natural decay of the chamber $\left(\lambda n=0.11 \mathrm{~h}^{-1}\right)$ and the decay rate of the plastic container $\left(\lambda p=0.15 \mathrm{~h}^{-1}\right)$ were subtracted from the total decay rate (Tables 1 and 2$)$.

Figure 4 presents the depletion of formaldehyde when expanded clay was tested, under dry and wet conditions, indicating that wet expanded clay was more effective on depleting formaldehyde than under dry conditions. Among all the conditions tested, soil was the most effective element to reduce formaldehyde in the chamber, especially under wet conditions (Figure 5). Figure 6 shows that activated carbon under dry conditions was more efficient than under wet conditions in reducing formaldehyde in the chamber.

Regarding formaldehyde depletion, potted plants $\left(0.03 \mathrm{~m}^{3} / \mathrm{h}\right)$ were as effective as dry activated carbon $\left(0.03-0.04 \mathrm{~m}^{3} / \mathrm{h}\right)$, less effective, in general, than soil $\left(0.07-0.16 \mathrm{~m}^{3} / \mathrm{h}\right)$, less effective than wet expanded clay $\left(0.04-0.16 \mathrm{~m}^{3} / \mathrm{h}\right)$, and as effective as dry expanded clay $\left(0.02-0.04 \mathrm{~m}^{3} / \mathrm{h}\right)$ (Table 1$)$. The selected plants (Boston fern and peace lily) present similar performance regarding formaldehyde removal (Figure 7).

With regard to $\mathrm{CO}_{2}$ levels, potted plants seemed to be the only test condition that reduced $\mathrm{CO}_{2}$, of which Boston fern was the most effective (Table 2), while in the case of activated carbon and soil, the levels of $\mathrm{CO}_{2}$ seemed to increase in the chamber.

Table 1 shows that under dry conditions inside of the chamber, the selected soil adsorbed formaldehyde faster than the other substrates, while the performance of the dry expanded clay was the lowest. The wet soil and expanded clay performed better than the dry conditions tested. Furthermore, Table 1 shows that the selected plants together with the substrate did not perform as well as the wet substrates, but, in general, they performed better than the dry substrates, with the exception of the dry soil. Regarding leaf area, the 
selected plants had similar characteristics in size and number of leaves; therefore, for every species, one plant was selected, and all its leaves were measured. Consequently, it was considered that the area of the other two plants of the selected species were in the same area range. In general, the peace lilies (approx. $0.14 \mathrm{~m}^{2}$ ) had more leaf area than the Boston ferns (approx. $0.11 \mathrm{~m}^{2}$ ).

\section{Discussion}

This study provides data for the characterization of the removal of formaldehyde by three different substrates and two different potted plants. Four series of zero measurements were executed to evaluate the setup. Two measurements of these series were executed with a plastic pot to evaluate the effect of this element in the depletion of the formaldehyde inside of the chamber. As expected, once the plastic pot was placed in the chamber, the formaldehyde level was lower than the natural decay measured during the zero-measurement evaluation. This value was used to calculate the CADR for every test condition, as shown in Tables 1 and 2.

\subsection{Depletion of Formaldehyde}

Exploration of the potential of plants to purify air from pollutants started in the early 1980s [23,41], and, to date, several plant species have been studied and identified for use in formaldehyde removal. However, previous studies have tested extremely high concentrations of formaldehyde (over $\sim 2000 \mu \mathrm{g} / \mathrm{m}^{3}$ ) [21], higher than the concentrations that are usually found in common indoor environments [1]. This study presents the results of the uptake of formaldehyde with a concentration of $300 \mathrm{ppb}\left(0.37 \mathrm{mg} / \mathrm{m}^{3}\right)$, which is within the boundaries of the detection threshold of formaldehyde indoors $\left(0.03 \mathrm{mg} / \mathrm{m}^{3}-0.6\right.$ $\left.\mathrm{mg} / \mathrm{m}^{3}\right)$ [1] and close to the guideline value based on sensory effects $\left(0.1 \mathrm{mg} / \mathrm{m}^{3}\right)$ [1] (WHO 2010). Furthermore, formaldehyde is soluble in water [1]; therefore, it may be depleted faster in wet environments [25]. In a study published in 2011, Aydogan and Montoya reported that activated carbon alone showed the highest formaldehyde removal and the four plant species studied demonstrated similar abilities to remove formaldehyde [25]. During this set of experiments, the reduction of formaldehyde concentration inside of the chamber was faster when wet substrates were present, and the plant species had similar behavior in formaldehyde removal $\left(\sim 0.03 \mathrm{~m}^{3} / \mathrm{h}\right)$. However, activated carbon appeared to be a very unstable component. Activated carbon did not have an optimal performance in any of the cases. Figure 6 presents the results of the effect of dry activated (AC_D; $n=3$ ) and wet activated carbon $\left(\mathrm{AC}_{-} \mathrm{W} ; n=2\right)$ on the depletion of formaldehyde in the chamber. The third sample of wet activated carbon was excluded because, instead of reducing the formaldehyde concentration, the wet activated carbon released it into the chamber. The third sample of the wet activated carbon came from a different package than the other samples. The packaging material was most likely polluted, which might have caused the unstable behavior of the selected substrate.

Previous studies suggest that the depletion of formaldehyde also occurs due to photosynthesis and metabolism of the plant at daytime [42]. A growing light was used during this test to ensure the optimal conditions of the plant.

Studies with potted plants in closed chambers continue to be useful for isolating factors that may enhance removal efficiency and contribute towards the improvement of plant-based systems (e.g., plant species and growth medium). Therefore, it is recommended to use the lessons learned from this study in creating plant-assisted botanical purifiers ("biowalls" or active green walls), which mechanically force the air to pass through the leaves and the roots $[23,43,44]$.

\subsection{Depletion of $\mathrm{CO}_{2}$}

For the evaluation of the reduction of $\mathrm{CO}_{2}$ levels inside of the chamber, it is important to mention that, in general, plants regulate the internal $\mathrm{CO}_{2}$ concentration through a partial stomatal closure when the $\mathrm{CO}_{2}$ concentration is too elevated to maintain adequate internal 
$\mathrm{CO}_{2}$ and optimize water use efficiency [45]. Stomata are pores on leaf epidermis for both water and $\mathrm{CO}_{2}$ fluctuations that are controlled by two major factors: stomatal behavior and density [46,47]. The fast speed of opening and closing of the stomata can save energy and increase photosynthesis and water-use efficiency [48]. Taking this into account, Table 2 and Figure 8 present the depletion of $\mathrm{CO}_{2}$ inside the chamber when the potted plants were present, and they show that even though the leaf area of the Boston fern is lower than the peace lily, the depletion of $\mathrm{CO}_{2}$ inside of the chamber was faster when the Boston fern was in the chamber. In order to ensure the optimal behavior of the plant during the experiments, levels of $\mathrm{CO}_{2}$ were controlled [45-47]. Figure 8 shows that in order to provide the optimal conditions for the plants, it was necessary to inject $\mathrm{CO}_{2}$ inside of the chamber when the Boston ferns were tested because the concentration of $\mathrm{CO}_{2}$ became too low for the ferns' wellbeing [35,36]. In each test condition, activated carbon permanently released $\mathrm{CO}_{2}$ inside of the chamber, which possibly could be compensated by the uptake of $\mathrm{CO}_{2}$ by the plants.

\subsection{Plants vs. Growth Media}

Formaldehyde and $\mathrm{CO}_{2}$ were used as indicators of the effect of growth media and plants in reducing gaseous pollutants in a controlled environment. Table 1 shows that, in general, growth media were more effective in the depletion of formaldehyde inside of the chamber than the plants. Regarding $\mathrm{CO}_{2}$ reduction inside of the chamber, as expected, Table 2 shows that plants were more effective than growth media: in most of the cases with only a growth medium present, $\mathrm{CO}_{2}$ was released instead of reduced inside of the glass chamber. Figure 9 presents the different behaviors of the potted plants regarding these two elements. Even though the leaf area of the Boston fern (approx. $0.11 \mathrm{~m}^{2}$ ) was smaller than the peace lily (approx. $0.14 \mathrm{~m}^{2}$ ), the Boston ferns reduced the concentration of $\mathrm{CO}_{2}$ inside of the chamber faster than the peace lilies, which indicates that the stomatal conductance of the Boston fern was higher than the peace lily, opening the hypothesis about the uptake of more gaseous pollutants by the stomata. Regarding the depletion of formaldehyde, in general, wet soil, dry soil, and expanded clay perform similarly and they are more effective than the other variables tested.

As mentioned before, formaldehyde is soluble in water [1]. However, this study shows that high levels of humidity seemed to have no effect on the formaldehyde depletion inside of the chamber, because in most of the test conditions, the relative humidity level was above $90 \%$. Nonetheless, it is important to mention that in the case of the plants, high humidity levels may affect the depletion of the $\mathrm{CO}_{2}$ and the formaldehyde inside of the chamber due to the fact that plants close their stomata at high humidity levels $[46,47]$. The temperature was quite stable during the experiments (Tables 1 and 2); therefore, it seemed to have no effect on the formaldehyde and $\mathrm{CO}_{2}$ depletion, but, in general, in the presence of wet growth media, the depletion of formaldehyde was faster. Regarding the effect of the growth media on the depletion of formaldehyde and $\mathrm{CO}_{2}$, it is important to mention that when the substrate (wet or dry) was tested without the plant, the whole surface of the substrate was exposed directly to formaldehyde and $\mathrm{CO}_{2}$. However, when the plants were included, the exposed surface of the selected substrate was reduced and the results show that the depletion was also lower, which indicates that the efficacy of the growth media, in some cases, was higher. This effect is produced by the microbial activity in the root zone, where bacteria absorb the gaseous pollutants and metabolize them [22-25].

\subsection{Potted Plants and Their Effect on the Indoor Air Quality}

According to the ASHRAE standard 62.1-2016, the minimum ventilation rate in breathing zones in office spaces is $0.31 / \mathrm{s}, \mathrm{m}^{2}\left(1.08 \mathrm{~m}^{3} / \mathrm{h}\right.$ for every one square meter of floor space) [49]; likewise, the standard NEN-EN 15251-2007 the minimum ventilation rate for new buildings and renovations is $0.35 \mathrm{l} / \mathrm{s}, \mathrm{m}^{2}\left(1.26 \mathrm{~m}^{3} / \mathrm{h}\right.$ for every one square meter of floor space) for very low-polluting buildings [50]. Table 1 shows that the CADR for formaldehyde depletion of the potted plants is $0.03 \mathrm{~m}^{3} / \mathrm{h}$; therefore, it is necessary to have 42 plants for every square meter of floor space in order to meet the standards without any 
additional ventilation system. Furthermore, Table 2 shows that the $\mathrm{CADR}$ for $\mathrm{CO}_{2}$ depletion of the potted plants is $0.01 \mathrm{~m}^{3} / \mathrm{h}$ (peace lily) and $0.02 \mathrm{~m}^{3} / \mathrm{h}$ (Boston fern). Therefore, it is necessary to have $>100$ plants for every square meter of floor space in order to meet the standards without any additional ventilation system. Thus, without any extra mechanical ventilation, an indoor forest is necessary to meet the minimum standards for ventilation rates in breathing zones just with plants; however, in real situations, less plants will be required, taking into account the size of the room and the ventilation system of every case.

\subsection{Limitations}

One of the limitations of this group of tests is the size of the chamber. Even though it has the requirements of a sealed glass container with the necessary inlets, for future research, it is recommended to execute the tests in a bigger sealed glass container to prevent or reduce the stress of the plant, avoiding the closure of its stomata and reducing its metabolism.

As mentioned before, plant stress should be minimized; therefore, for future experiments, the plant should be placed in the chamber one day prior to the execution of the test together with the activated growing light.

\section{Conclusions and Recommendations}

A series of tests was performed to evaluate the effect of potted plants on reducing formaldehyde and $\mathrm{CO}_{2}$ levels in a controlled glass chamber. The outcome of the tests showed some clear advantages and disadvantages of the different test conditions to consider for the design of an indoor plant-based system.

In terms of air "cleaning" of formaldehyde, the measurements and analysis showed that soil, in general, was most effective in reducing formaldehyde concentrations in the chamber $\left(\sim 0.07-0.16 \mathrm{~m}^{3} / \mathrm{h}\right)$. Plants $\left(\sim 0.03 \mathrm{~m}^{3} / \mathrm{h}\right)$ were as effective as dry expanded clay $\left(0.02-0.04 \mathrm{~m}^{3} / \mathrm{h}\right)$. Wet and dry soil, wet expanded clay, and dry activated carbon performed better than the selected plants in formaldehyde depletion. In this study, it became clear that the substrate is an important ally in reducing gaseous pollutants such as formaldehyde.

Regarding $\mathrm{CO}_{2}$ reduction in the chamber, potted plants (peace lilies: $0.01 \mathrm{~m}^{3} / \mathrm{h}$ ) (Boston ferns: $0.02-0.03 \mathrm{~m}^{3} / \mathrm{h}$ ) were more effective than the other tests, especially Boston fern, which has a higher stomatal conductance than the peace lily, indicating the possibility of allowing more gaseous pollutants to be absorbed in the long term.

Studies with potted plants in closed chambers were shown to be useful for isolating factors that may enhance removal efficiency and contribute towards the improvement of plant-based systems (e.g., plant species and growth medium). However, the impact of one potted plant on the cleaning of the indoor air was insignificant. Therefore, several potted plants will be required to improve the IAQ, taking into account the specific characteristics of the place, such as size and the ventilation system.

It must be noted, however, that in this study, the formaldehyde was introduced in a glass chamber in which the plant and its substrate were located, hereby surrounding the plant and its substrate with formaldehyde. In a "normal" indoor environment, usually the source of formaldehyde may not be close to the plant system. For the plant system to take up the formaldehyde, the polluted air needs to be transported to the vicinity of the plant. This could be realized, for example, by an active plant-substrate system, in which the contaminated air is forced to go through the plant leaves and through the substrate roots. Further research with active plant-based systems on the depletion of formaldehyde and other pollutants is required.

Author Contributions: Conceptualization, T.A.-M., P.M.B. and P.d.V.; methodology, T.A.-M., P.M.B. and P.d.V.; formal analysis and investigation, T.A.-M. and P.M.B.; data curation, T.A.-M.; writingoriginal draft preparation, T.A.-M., writing—review and editing, T.A.-M., M.O., A.v.d.D. and P.M.B.; visualization, T.A.-M.; supervision, P.d.V., M.O., A.v.d.D. and P.M.B. All authors have read and agreed to the published version of the manuscript. 
Funding: This research received no external funding.

Institutional Review Board Statement: The study did not involve humans.

Informed Consent Statement: The study did not involve humans.

Data Availability Statement: More information on the data presented in this study is available on request from the corresponding author.

Acknowledgments: The work described in this paper is part of a PhD project, supported by the National Secretariat of Higher Education, Science, Technology and Innovation of Ecuador (Senescyt) and Delft University of Technology. The authors would like to express their gratitude to the Wageningen Plant Research Group at Wageningen University for their skillful help and support during the performance of this set of experiments in their laboratory. Ton van der Zalm and Claire van Haren are thanked for their help during the execution of the experiments.

Conflicts of Interest: The authors declare no conflict of interest.

\section{References}

1. WHO. WHO Guidelines for Indoor Air Quality: Selected Pollutants; World Health Organization: Geneva, Switzerland, 2010.

2. Kotzias, D.; Koistinen, K.; Schlitt, C.; Carrer, P.; Maroni, M.; Jantunen, M. The INDEX Project: Final Report for Critical Appraisal of the Setting and Implementation of Indoor Exposure Limits in the EU; Institute for Health and Consumer Protection: Ispra, Italy, 2005.

3. Kotzias, D. Indoor air and human exposure assessment-Needs and approaches. Exp. Toxicol. Pathol. 2005, 57, 5-7. [CrossRef]

4. Brown, S.K.; Sim, M.R.; Abramson, M.J.; Gray, C.N. Concentrations of volatile organic-compounds in indoor air-A review. Indoor Air-Int. J. Indoor Environ. Health 1994, 4, 123-134. [CrossRef]

5. $\quad$ Bluyssen, P.M.; de Oliveira Fernandes, E.; Groes, L.; Clausen, G.; Fanger, P.O.; Valbjørn, O.; Bernhard, C.A.; Roulet, C.A. European indoor air quality audit project in 56 office buildings. Indoor Air Int. J. Indoor Environ. Health 1996, 6, 221-238. [CrossRef]

6. Bluyssen, P.M.; Cochet, C.; Fischer, M.; Knöppel, H.; Levy, L.; Lundgren, B.; Maroni, M.; Mølhave, L.; Rothweiler, H.; Saarela, K.; et al. Evaluation of VOC Emissions from Building Products: Solid Flooring Materials; European Collaborative Action: Brussels, Belgium; Luxembourg, 1997.

7. Sofuoglu, S.C.; Aslan, G.; Inal, F.; Sofuoglu, A. An assessment of indoor air concentrations and health risks of volatile organic compounds in three primary schools. Int. J. Hygiene Environ. Health 2011, 214, 36-46. [CrossRef]

8. Campagnolo, D.; Saraga, D.E.; Cattaneo, A.; Spinazzè, A.; Mandin, C.; Mabilia, R.; Perreca, E.; Sakellaris, I.; Canha, N.; Mihucz, V.G.; et al. VOCs and aldehydes source identification in European office buildings-The OFFICAIR study. Build. Environ. 2017, 115, 18-24. [CrossRef]

9. Yu, C.; Crump, D. A review of the emission of VOCs from polymeric materials used in buildings. Build. Environ. 1998, 33, 357-374. [CrossRef]

10. Bluyssen, P.M. The Indoor Environment Handbook: How to Make Buildings Healthy and Comfortable; Taylor \& Francis: London, UK, 2009.

11. Wolkoff, P. Trends in Europe to reduce the indoor air pollution of VOCs. Indoor Air 2002, 13, 5-11. [CrossRef] [PubMed]

12. IARC. Formaldehyde, 2-Butoxyethanol and 1-Tert-Butoxy-2-Propanol; International Agency for Research on Cancer: Lyon, France, 2006.

13. Nielsen, G.D.; Wolkoff, P. Cancer effects of formaldehyde: A proposal for an indoor air guideline value. Arch. Toxicol. 2010, 84, 423-446. [CrossRef] [PubMed]

14. Salthammer, T.; Mentese, S.; Marutzky, R. Formaldehyde in the Indoor Environment. Chem. Rev. 2010, 110, 2536-2572. [CrossRef]

15. Knoeppel, H.; Molhave, L.; Seifert, B. Indoor Air Pollution by Formaldehyde in European Countries; EUR 13216 EN; JRC7582; CEC: Brussels, Belgium; Luxembourg, 1990.

16. Haghighat, F.; De Bellis, L. Material emission rates: Literature review, and the impact of indoor air temperature and relative humidity. Build. Environ. 1998, 33, 261-277. [CrossRef]

17. Kaden, D.; Mandin, C.; Nielsen, G.D.; Wolkoff, P. Formaldehyde. In WHO Guidelines for Indoor Air Quality: Selected Pollutants; World Health Organization: Geneva, Switzerland, 2010; pp. 103-156.

18. WHO. Organic Pollutants, in Air Quality Guidelines for Europe; World Health Organization: Geneva, Switzerland, $2000 ;$ pp. 58-121.

19. Van Gemert, L.J. Compilations of odour threshold values in air, water and other media. In Part 1: Odour Threshold Values in Air; Oliemans, Punter \& Partners BV: Zeist, The Nehterlands, 2011; pp. 11-181.

20. Soreanu, G.; Dixon, M.; Darlington, A. Botanical biofiltration of indoor gaseous pollutants-A mini-review. Chem. Eng. J. 2013, 229, 585-594. [CrossRef]

21. Dela Cruz, M.; Christensen, J.H.; Thomsen, J.D.; Müller, R. Can ornamental potted plants remove volatile organic compounds from indoor air?-A review. Environ. Sci. Pollut. Res. 2014, 21, 13909-13928. [CrossRef]

22. Irga, P.J.; Pettit, T.; Torpy, F. The phytoremediation of indoor air pollution: A review on the technology development from the potted plant through to functional green wall biofilters. Rev. Environ. Sci. Bio/Technol. 2018, 17, 395-415. [CrossRef]

23. Armijos Moya, T.; van den Dobbelsteen, A.; Ottelé, M.; Bluyssen, P.M. A review of green systems within the indoor environment. Indoor Built. Environ. 2019, 28, 298-309. [CrossRef] 
24. Wolverton, B.C.; Johnson, A.; Bounds, K. Interior Landscape Plants for Indoor Air Pollution Abatement; National Aeronautics and Space Administration: Hancock County, MS, USA, 1989; pp. 1-22.

25. Aydogan, A.; Montoya, L.D. Formaldehyde removal by common indoor plant species and various growing media. Atmos. Environ. 2011, 45, 2675-2682. [CrossRef]

26. Torpy, F.; Zavattaro, M.; Irga, P. Green wall technology for the phytoremediation of indoor air: A system for the reduction of high $\mathrm{CO}_{2}$ concentrations. Air Qual. Atmos. Health 2016, 10, 575-585. [CrossRef]

27. Torpy, F.; Clements, N.; Pollinger, M.; Dengel, A.; Mulvihill, I.; He, C.; Irga, P. Testing the single-pass VOC removal efficiency of an active green wall using methyl ethyl ketone (MEK). Air Qual. Atmos. Health 2018, 11, 163-170. [CrossRef]

28. Sandhu, A.; Halverson, L.J.; Beattie, G.A. Bacterial degradation of airborne phenol in the phyllosphere. Environ. Microbiol. 2006, 9 , 383-392. [CrossRef]

29. Khaksar, G.; Treesubsuntorn, C.; Thiravetyan, P. Effect of endophytic Bacillus cereus ERBP inoculation into non-native host: Potentials and challenges for airborne formaldehyde removal. Plant Physiol. Biochem. 2016, 107, 326-336. [CrossRef]

30. Wood, R.A.; Orwell, R.L.; Tarran, J.; Torpy, F.; Burchett, M. Potted-plant/growth media interactions and capacities for removal of volatiles from indoor air. J. Hortic. Sci. Biotechnol. 2002, 77, 120-129. [CrossRef]

31. Orwell, R.L.; Wood, R.L.; Tarran, J.; Torpy, F.; Burchett, M.D. Removal of Benzene by the Indoor Plant/Substrate Microcosm and Implications for Air Quality. Water Air Soil Pollut. 2004, 157, 193-207. [CrossRef]

32. Kim, K.J.; Kil, M.J.; Song, J.S.; Yoo, E.H.; Son, K.-C.; Kays, S.J. Efficiency of Volatile Formaldehyde Removal by Indoor Plants: Contribution of Aerial Plant Parts versus the Root Zone. J. Am. Soc. Hortic. Sci. 2008, 133, 521-526. [CrossRef]

33. Wolverton, B.C.; Wolverton, J.D. Plants and soil microorganisms: Removal of formaldehyde, xylene, and ammonia from the indoor environment. J. Miss. Acad. Sci. 1993, 38, 11-15.

34. Liu, Y.J.; Mu, Y.J.; Zhu, Y.G.; Ding, H.; Arens, N.C. Which ornamental plant species effectively remove benzene from indoor air? Atmos. Environ. 2007, 41, 650-654. [CrossRef]

35. IPCC. Climate Change 2014: Synthesis Report; Contribution of Working Groups I, II and III to the Fifth Assessment Report of the Intergovernmental Panel on Climate Change: Geneva, Switzerland, 2014; pp. 1-151.

36. NASA. Carbon Dioxide: Direct Measurements: 2005-Present. Available online: https://climate.nasa.gov (accessed on 10 November 2019).

37. Zheng, Y.; Li, F.; Hao, L.; Shedayi, A.A.; Guo, L.; Ma, C.; Huang, B.; Xu, M. The optimal $\mathrm{CO}_{2}$ concentrations for the growth of three perennial grass species. BMC Plant Biol. 2018, 18, 1-12. [CrossRef]

38. Irga, P.; Paull, N.; Abdo, P.; Torpy, F. An assessment of the atmospheric particle removal efficiency of an in-room botanical biofilter system. Build. Environ. 2017, 115, 281-290. [CrossRef]

39. EPA. Evaluation of In-Room Particulate Matter Air Filtration Devices; Environmental Protection Agency: Washington, DC, USA, 2008

40. ANSI/AHAM-AC-1-2013. Method for Measuring Performance of Portable Household Electric Room Air Cleaners; Association of Home Appliance Manufacturers: Washington, DC, USA, 2015.

41. Wolverton, B.C.; Mcdonald, R.C.; Watkins, E.A. Foliage plants for removing indoor air-pollutants from energy-efficient homes. Econ. Bot. 1984, 38, 224-228. [CrossRef]

42. Teiri, H.; Pourzamani, H.; Hajizadeh, Y. Phytoremediation of VOCs from indoor air by ornamental potted plants: A pilot study using a palm species under the controlled environment. Chemosphere 2018, 197, 375-381. [CrossRef]

43. Darlington, A.; Chan, M.; Malloch, D.; Pilger, C.; A Dixon, M. The Biofiltration of Indoor Air: Implications for Air Quality. Indoor Air 2000, 10, 39-46. [CrossRef]

44. Cummings, B.E.; Waring, M.S. Potted plants do not improve indoor air quality: A review and analysis of reported VOC removal efficiencies. J. Expo. Sci. Environ. Epidemiol. 2019, 30, 253-261. [CrossRef]

45. Van de Geijn, S.C.; Goudriaan, J. The effects of elevated $\mathrm{CO}_{2}$ and temperature change on transpiration and crop water use. In Global Climate Change and Agricultural Production; FAO and John Wiley \& Sons: Oxford, UK, 1996; pp. 101-121.

46. Wang, Y.; Chen, X.; Xiang, C.-B. Stomatal Density and Bio-water Saving. J. Integr. Plant Biol. 2007, 49, 1435-1444. [CrossRef]

47. Elliott-Kingston, C.; Haworth, M.; Yearsley, J.M.; Batke, S.; Lawson, T.; McElwain, J.C. Does Size Matter? Atmospheric CO 2 May Be a Stronger Driver of Stomatal Closing Rate Than Stomatal Size in Taxa That Diversified under Low $\mathrm{CO}_{2}$. Front. Plant Sci. 2016, 7, 1253. [CrossRef] [PubMed]

48. Grantz, D.A.; Assmann, S.M. Stomatal response to blue light: Water use efficiency in sugarcane and soybean. Plant Cell Environ. 1991, 14, 683-690. [CrossRef]

49. ASHRAE-62.1. Ventilation for Acceptable Indoor Air Quality; American Society of Heating, Refrigerating and Air Conditioning Engineers: Atlanta, GA, USA, 2016.

50. NEN-EN15251. Indoor Environmental Input Parameters for Design and Assessment of Energy Performance of Buildings Addressing Indoor Air Quality, Thermal Environment, Lighting and Acoustics; European Committee for Standardization: Brussels, Belgium, 2007. 